\title{
W nieznane. Zaświaty i tanatyczne katharsis w serialu animowanym Po drugiej stronie muru Patricka McHale'a
}

\section{Abstrakt:}

Śmierć, smutek, wyobcowanie, zagubienie - to tematy, które rzadko kojarzone są z serialami animowanymi dla dzieci. Istnieją jednak wieloodcinkowe programy telewizyjne, które - podobnie jak książki, gry wideo i filmy - poruszają wspomniane kwestie, a są przeznaczone dla młodych odbiorców. W ten sposób nie tylko przełamują kulturowe tabu, lecz także oferują estetykę i wrażliwość, które uzupełniają obraz głównonurtowych produkcji dla dzieci jako beztroskich i wesołych. Ciekawym przykładem animacji, która w nietypowy sposób radzi sobie z opowiadaniem m.in. o strachu czy śmierci, ukazując je na tle przygody i wędrówki, jest serial Po drugiej stronie muru Patricka McHale’a (2014). Autorzy artykułu skupiają się na tym, jak dzieło wchodzi w rezonans nie tylko ze wspomnianymi wyżej motywami, lecz także z historią oraz kulturą popularną. Analiza prowadzi to wniosku, że Po drugiej stronie muru to serial intertekstualny, otwarty na interpretacje zarówno młodszych, jak i starszych odbiorców, a także umożliwiający przeżycie tanatycznego katharsis - oczyszczenia z negatywnych uczuć związanych ze śmiercią i stratą.

\section{Słowa kluczowe:}

animacja, Cartoon Network, katharsis, kultura dziecięca i młodzieżowa, kultura popularna, Patrick McHale, Po drugiej stronie muru, serial telewizyjny, śmierć, tanatyzm

* Piotr Prósinowski - mgr, przygotowuje rozprawę doktorską w Instytucie Pedagogiki Wydziału Nauk Społecznych Uniwersytetu Gdańskiego dotyczącą wychowania w kontekście gier wideo; prezes Fundacji Inicjatywa Nox. Kontakt: piotr.games.research@gmail.com.

** Piotr Krzywdziński - mgr, wiceprezes Fundacji Inicjatywa Nox. Jego zainteresowania badawcze obejmują gry wideo, literaturę piękną, kulturę współczesną oraz metodologię prowadzenia badań społecznych. Kontakt: krzywdzinski.piotr@gmail.com. 


\section{Into the Unknown: The Underworld and Thanatic Catharsis in the Animated Series Over the Garden Wall by Patrick McHale}

\section{Abstract:}

Death, sadness, alienation, and confusion are themes that are rarely associated with children's animated series. Nevertheless, there are multi-episode TV programs that - similarly to books, video games, and films - raise such issues even though they are created for young viewers. In that way, they not only break the cultural taboo, but also offer aesthetics and sensitivity that complement the image of mainstream children's programming as laid-back and cheerful. As an interesting example, one might point to Patrick McHale's Over the Garden Wall (2014), an animated series that deals with such themes as fear or death in a unique way, showing them against the background of adventure and wandering. In this article, the authors focus on the ways in which the work resonates with the mentioned motifs, but also with history and popular culture. The analysis leads to a conclusion that Over the Garden Wall is an intertextual series, open to interpretation for younger and older viewers alike, as well as enabling the experience of a Thanatic catharsis - a cleansing from the negative feelings associated with death and loss.

\section{Key words:}

animation, Cartoon Network, catharsis, children's and young adult culture, popular culture, Patrick McHale, Over the Garden Wall, TV series, death, thanatism

\section{Wprowadzenie}

W myśleniu potocznym o filmach animowanych i telewizyjnych kreskówkach wciąż obecny jest ich stereotypowy obraz jako tętniących życiem, niedojrzałych produkcji rozgrywających się $\mathrm{w}$ barwnych sceneriach. Wiele animacji, owszem, już swoją estetyką może budzić w niektórych odbiorcach wrażenie niepowagi - zwłaszcza gdy patrzy się na nie w sposób powierzchowny ${ }^{1}$. Przyczyną podobnych reakcji mogą być np. abstrakcyjność świata Pory na przygodę! (Ward, 2010-2018), wizualna oraz tematyczna figlarność i nietypowość Niesamowitego świata Gumballa (Bocquelet, 2011-2019) czy barwna różnorodność Stevena Universe’a (Sugar, 2013-2019). Wszystkie te popularne

1 Część badań sugeruje, że postrzeganie kreskówek może być silnie uzależnione od statusu socjoekonomicznego i poziomu wykształcenia rodziców (İvrendi, Özdemir, 2010). Niższy poziom wykształcenia sprzyjać ma negatywnym postawom wobec produkcji animowanych. Wydaje się to powiązane z potocznym przeświadczeniem o niższości telewizji względem innych mediów (Mittel, 2013, s. 56). 
produkcje pozornie sprawiają wrażenie reprezentacji kultury niepoważnej. Jednocześnie - tak na poziomie formy, jak treści, czyli opowiadanej historii wpisują się w trend poszukiwań artystycznych i przekraczania obyczajowego tabu we współczesnych serialach i filmach animowanych (Mąka-Malatyńska, 2016, s. 144)

Część dorosłych odbiorców widzi w animacjach to, co „niegrzeczne” i „niestosowne”. W efekcie powstają alarmistyczne raporty, np. Wolves in Sheep's Clothing: A Content Analysis of Children's Television [Wilki w owczej skórze. Analiza treściowa telewizji dziecięcej] (Fyfe, 2005), w których wytyka się palcami treści budzące niepokój w bardziej konserwatywnych kręgach społecznych. Dotyczy to m.in. niektórych rodziców - zachowanie pewnego percepcyjnego dystansu może sprawić im trudność, zwłaszcza w przypadku odnoszenia się danej animacji do tego, jak z dziecięcej perspektywy mogą być postrzegani dorośli opiekunowie czy nauczyciele (np. jako grupy reprezentujące wartości przeciwstawne do tych łączonych z młodością i dzieciństwem). Wydaje się, że uwidacznia się tu konflikt o postulowany kształt mediów dziecięcych ( $w$ tym literatury i kinematografii skierowanych m.in. do młodych czytelników i widzów), jak również różne wyobrażenia na temat dzieciństwa oraz dynamiki relacji władzy między dorosłymi i dziećmi, co jest istotne także dla antypedagogiki.

Można też, oczywiście, nawiązać w tym miejscu do myśli romantycznej i wizji dziecka jako wyidealizowanego awatara czystości (Pugh, 2011, s. 4). Takie postrzeganie dzieciństwa oraz niedorosłych jest często sygnalizowane również w kontekście badania literatury dziecięcej i młodzieżowej (Hunt, 2004/2008; Spuffort, 2002). Należy jednak pamiętać, że dzieci nie są jedynie uosobieniami dobra i niewinności (Nikolajeva, 2003, s. 146; Slany, 2016, s. 162-163), ale - jak każda jednostka ludzka - mają potencjał do operowania pełnym wachlarzem zachowań oraz mogą odczuwać potrzebę doznawania różnych uczuć i stanów, także złości, smutku czy niepewności (Sorin, 2003, s. 82). Te emocje wpisane są w naturę człowieka, a dziecko, będąc przede wszystkim właśnie człowiekiem, ma prawo przeżywać własne radości, smutki, przygody i horrory (s. 85-86).

Zagłębiając się w świat współczesnych animacji, możemy w nich dostrzec wiele istotnych odniesień kulturowych lub komentarzy dotyczących rzeczywistości (czy to w jej wymiarze społecznym, czy politycznym, ideologicznym, a nawet religijnym) - jak bowiem sądzi Tessa Moult-Milewska, animacja to „sztuka jak każda inna, która także widzi i opisuje świat” (Czubaszek, 2019). Wraz z innymi formami kultury współczesnej tworzy świat naszego doświadczenia (Szkudlarek, Melosik, 1998/2010, s. 97), tym samym wchodząc w swoistą synergię z naszym rozumieniem codzienności i otaczających zjawisk. $\mathrm{Na}$ tle wymienionych wcześniej animacji wyróżniają się mniej znane produkcje, 
które - chociaż nierzadko tworzone są przez te same studia i w ramach działalności tych samych korporacji, co najpopularniejsze tytuły - oferują zupełnie inną estetykę i atmosferę. Opowiadają m.in. o kwestiach budzących niepokój i grozę, operując postaciami ze snów i koszmarów. W ten sposób stają się dla odbiorców okazją do przeżycia wyjątkowego doświadczenia. Przykładem takiej animacji jest Po drugiej stronie muru ${ }^{2}$ Patricka McHale’a (2014), które jest w niniejszym artykule przedmiotem analizy i interpretacji. Skupiamy się przede wszystkim na tym, jak ta produkcja rezonuje z motywami strachu i śmierci, a także z historią oraz kulturą popularną. Celem tekstu jest zatem ukazanie intertekstualnego potencjału tego programu telewizyjnego, zwłaszcza w aspekcie wychowawczym.

\section{Po drugiej stronie muru - formalny opis produkcji}

Pomysłodawcą, producentem i głównym scenarzystą Po drugiej stronie muru jest wspomniany już Patrick McHale, znany również z pracy jako dyrektor kreatywny Pory na przygodę! i zaangażowania w produkcję Niezwykłych przypadków Flapjacka (Van Orman, 2008-2010). Wykreowana dla znanej także w Polsce stacji telewizyjnej Cartoon Network animacja składa się z dziesięciu odcinków, a każdy z nich trwa około jedenastu minut (Tymińska, 2016, s. 35).

Program powstał na podstawie innej miniprodukcji tego samego autora, trwającej niecałe dziesięć minut animacji Tome of the Unknown: Harvest Melody [Księga Nieznandii. Melodia żniw] (Browngardt, Funaro, McHale, 2013). Pierwowzór nie był emitowany w naszym kraju, natomiast Po drugiej stronie muru miało polską premierę w Cartoon Network pod koniec marca 2015 roku. W Stanach Zjednoczonych program był zaś wyświetlany na początku listopada 2014 roku - tym samym towarzyszył obchodom Halloween, przypadającym na 31 października. Atmosfera tego święta udziela się także samej produkcji.

Serial opowiada o dwójce przyrodnich braci - starszym, Wircie, oraz młodszym, Gregu - którzy znajdują się pośrodku wielkiego i gęstego lasu (co jednocześnie nawiązuje do popularnego motywu baśniowego) w fantastycznej krainie, Nieznandii [the Unknown]. Nie wiadomo, skąd się tam wzięli i jak mogą wrócić do domu. Już na początku przygody, w odcinku pierwszym pt. Stary młyn (Allegri, Gorman, Wolfhard, Cash, 2014), dołącza do nich błękitnik

2 Tytuł oryginalny to Over the Garden Wall, w Polsce serial wyświetlano też jako Za brama ogrodu. 
(ptak z rodziny drozdowatych) o imieniu Beatrice. Szukając drogi powrotnej, spotykają różne postacie, m.in. objaśniającego im realia tego świata Drzewiarza, odgrywającego funkcję humorystyczną Żabusia (pojawiającego się w serialu pod wieloma innymi imionami) oraz potwornego Bestiusza. Ostatni z nich to czyhające na braci monstrum, które podąża za nimi i obserwuje bohaterów z ukrycia, chcąc zamienić ich w widmodrzew - opał z tej rośliny jest wykorzystywany do podtrzymywania ognia latarni, gdzie przechowywana jest dusza antagonisty, co chroni go przed zagładą. Sprytny Bestiusz wykorzystuje do ochrony lampy Drzewiarza, który chroniąc światło, sądzi, że podtrzymuje życie córki, a w rzeczywistości staje się strażnikiem mrocznego żywota swojego oprawcy.

Wędrując po Nieznandii, bracia nie tylko poznają różne istoty, lecz także odwiedzają rozmaite miejsca i przeżywają liczne przygody. Mają nadzieję, że każdy kolejny krok zaprowadzi ich bliżej domu. Czy jest to jednak możliwe? Czy będą w stanie opuścić tę krainę? Pytania te są o tyle istotne, że końcowe odcinki serialu ujawniają prawdziwy, tragiczny powód obecności Wirta i Grega w Nieznandii - uciekając przed policją po halloweenowym spotkaniu ze znajomymi na cmentarzu, bracia unikają zderzenia z pociągiem, ale wpadają do zbiornika wodnego i tracą przytomność, by następnie obudzić się w niezwykłej czasoprzestrzeni. Ta zaś, biorąc pod uwagę okoliczności, interpretowana może być jako zaświaty, a sami bohaterowie - jako znajdujący się na granicy życia i śmierci.

\section{Po drugiej stronie muru - analiza kulturowa i interpretacja fragmentów produkcji}

Patrick McHale i pozostali twórcy Po drugiej stronie muru nie czerpią inspiracji wyłącznie z tradycyjnych baśni i klasycznych animacji, ale sięgają także do elementów konstrukcyjnych oraz innych aspektów literatury gotyckiej, wykorzystują liczne odniesienia kulturowe, przenoszą postaci literackie i historyczne do własnej opowieści (Tymińska, 2016, s. 35-37). Proponują też zabawę na poziomie graficznym, nawiązując do historii kinematografii - np. już w pierwszych scenach serialu widza witają plansze tytułowe, czołówki przypominające te znane z kina niemego (Allegri, Gorman, Wolfhard, Cash, 2014). Jednocześnie, na poziomie estetyki, Po drugiej stronie muru umiejętnie operuje stopniowym budowaniem napięcia i atmosfery grozy, jednymi z kluczowych elementów definiujących horror (Has-Tokarz, 2011, s. 50). 


\section{Aspekty wizualne}

Warstwa wizualna analizowanego serialu odróżnia go od wielu popularnych współcześnie animacji - widać to zwłaszcza na przykładzie kolorystyki. Barwy są najczęściej stonowane (z kilkoma wyjątkami, np. większym ich nasyceniem cechuje się scena w pokoju Wirta na początku odcinka dziewiątego pt. Droga w nieznane; Gorman, Nguyen, Sanchez, 2014), nierzadko wypłowiałe i przytłumione, a zastosowanie takiej palety $\mathrm{w}$ animacji ma znaczenie. Ciemne kolory - dominują czerń, brąz, ciemna zieleń itp. - nadają całości wymiar grozy i mają potencjał, by wprawić widzów w nastrój sprzyjający odbiorowi nie tylko treści, lecz także estetyki tej produkcji. Już sam początek historii wprowadza w świat nocy, mrocznych zakamarków, głębokich cieni, z którymi kontrastuje światło charakterystycznej latarni, zwracającej odbiorczą uwagę, ale jednocześnie podkreślającej ciemność wokół bohaterów - widać to na rysunku 1.

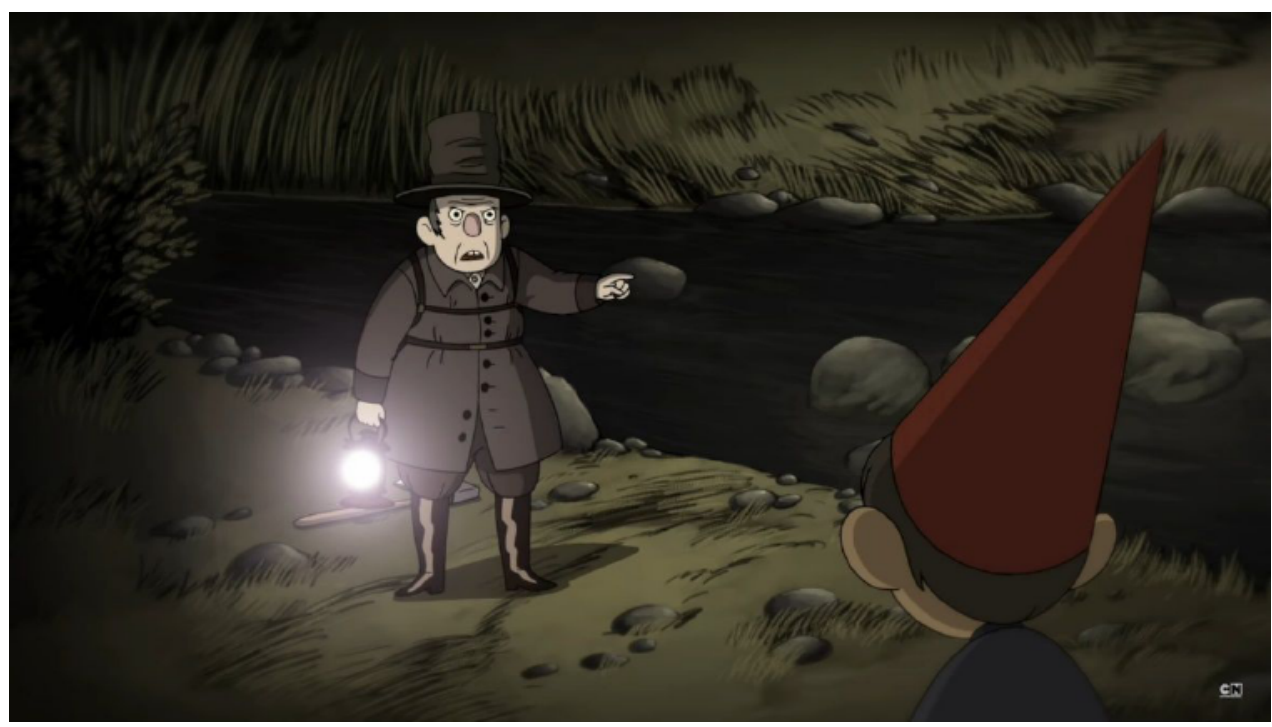

RYSUNEK 1. Wirt (po prawej) spotyka Drzewiarza (po lewej).

Kadr z odcinka Stary mlyn.

Ciemność jest zresztą silnie obecna w całej omawianej animacji. Spowija leśne ścieżki, drzewa i zwierzęta, tworzy zarówno przestrzeń istnienia bohaterów, jak i pole działania antagonisty. Można także przypomnieć, że czerń to barwa, która symbolicznie nawiązuje do śmierci, uwiądu czy strachu (Petru, 2010-2011, s. 1718). W tym przypadku jednak odnosi się także do sekretów - jako spowitych mrokiem, ukrytych, a odseparowanych od tego, co jasne 
i jawne. Tak tajemnice, jak uobecniające je czernie często pojawiają się w historii Wirta i Grega. Kolor nie jest wtórny względem fabuły, ale buduje rzeczywistość przygody, zakotwiczając ją w konkretnej atmosferze i symbolice.

Całości dopełniają inne barwy - zarówno bardziej nasycone, jak i blade, nienasycone - tworzące tło dla niektórych obiektów widocznych w kadrze: krwista czerwień, chłodny błękit, często pojawiające się brązy (w ich kolorze są m.in. powykręcane drzewa czy przestrzeń, z której płynnie wyłania się chata jednej z postaci - Adelajdy - w odcinku szóstym pt. Żabia kołysanka; Edward, Youn, Cash, 2014), zgniła zieleń leśnej trawy. Uzupełniają one kompozycję barwną, nadając jej ciekawych i istotnych akcentów - tłumaczących ciemność i jej konteksty na bardziej skomplikowane składnie wizualne, które nie wybijają jednak całości z grozotwórczego rytmu, a raczej dopełniają ją o dodatkowe konotacje i wydźwięki. W efekcie omawiana animacja zyskuje mroczny charakter.

Chociaż wiele postaci występujących w Po drugiej stronie muru ma uproszczone sylwetki, pozbawione dużej ilości detali, to opisane wyżej wykorzystanie barw „postarza” produkcję, wyróżniając ją na tle innych współczesnych seriali animowanych - uwzględniając także pozostałe produkcje Cartoon Network. W programie skorzystano też ze wspomnianych już stylizowanych plansz (jedną z nich ukazuje rysunek 2), których forma odwołuje się do tablic tytułowych dawnych filmów m.in. z epoki kina niemego (np. z Frankensteina na rysunku 3;

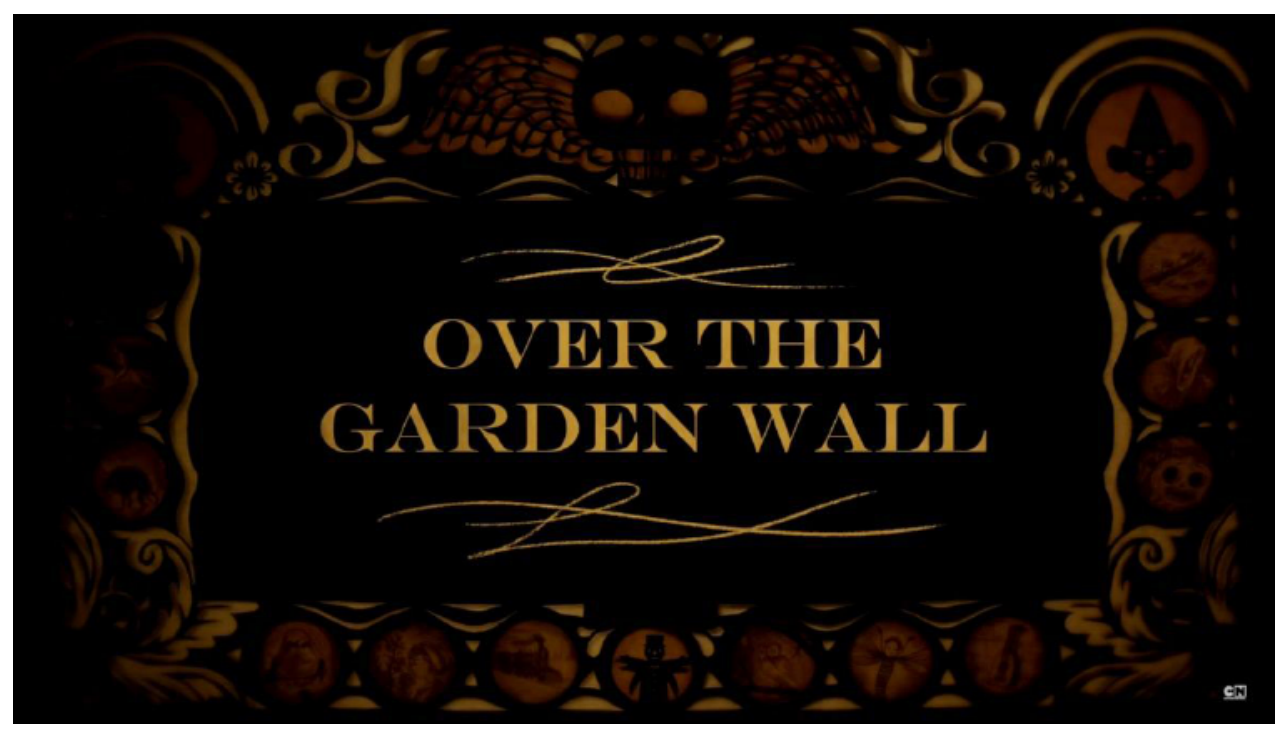

RYSUNEK 2. Plansza tytułowa. Kadr z odcinka Stary młyn. 


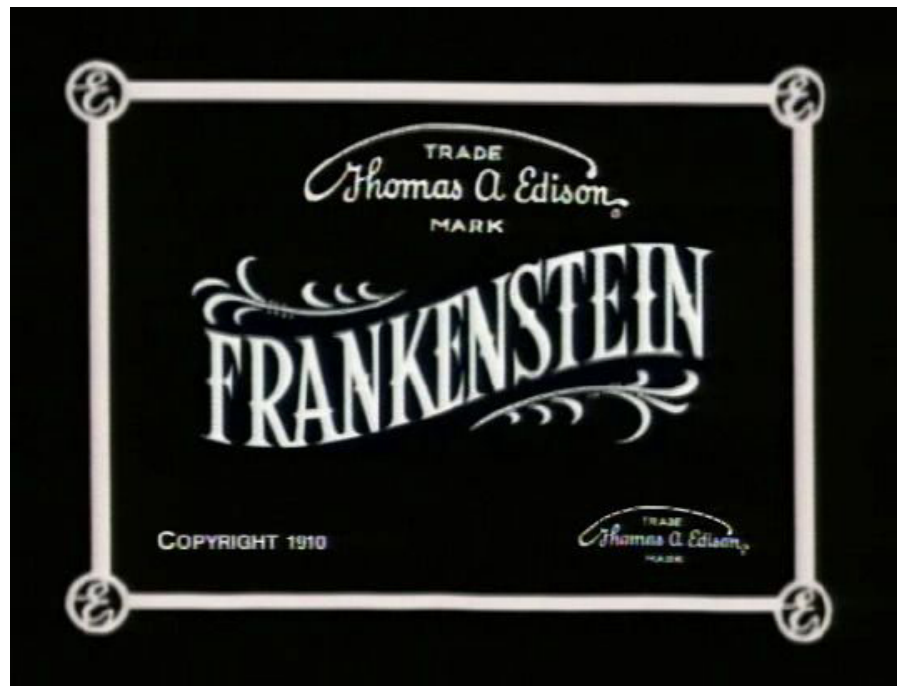

RYSUNEK 3. Plansza tytułowa. Kadr z filmu Frankenstein.

Dawley, Edison, 1910) oraz XVII- i XVIII-wiecznych tablic nagrobnych (jak ta zaprezentowana na rysunku 4). Ten element estetyki grozy - a zarazem swoiste dzieło sztuki w duchu sentencji memento mori, „wyryte” w animacji jak na dawnych kamieniach nagrobnych - zostaje wspomniany przez Martę Tymińską (2016), która analizując serial, dostrzega w nim także nawiązania do innych form artystycznych i pisze, że produkcja „ma bardzo malarski charakter, przy czym nie stroni też od karykatury” (s. 36).

Takie wykorzystanie grafiki jest intencjonalnym zabiegiem artystycznym wprowadzającym odbiorców w specyficzne uniwersum omawianej produkcji oraz jego estetykę, jak również stanowi jasne nawiązanie do śmierci i zaświatów. Nie da się zaprzeczyć, że można rozpoznać w warstwie wizualnej serialu McHale'a te same źródła inspiracji, które charakteryzują tzw. burtoneskę ${ }^{3}$ znaną m.in. z filmów Sok z żuka (Bender, Hashimoto, Wilson, Burton, 1988), Jeździec bez głowy (Rudin, Schroeder, Burton, 1999) i Gnijąca panna młoda (Abbate, Burton, Johnson, 2005). W ten sposób serial, podobnie jak kino Tima Burtona, balansuje na granicy komizmu i grozy, humoru i powagi, jawy i koszmaru - łącząc różne porządki estetyczne oraz proponując zabawę kształtem i kompozycją obrazu.

3 Styl charakterystyczny dla większości filmów Tima Burtona: mroczny, groteskowy, karykaturalny, zakładający zabawę kompozycją i kształtem. 


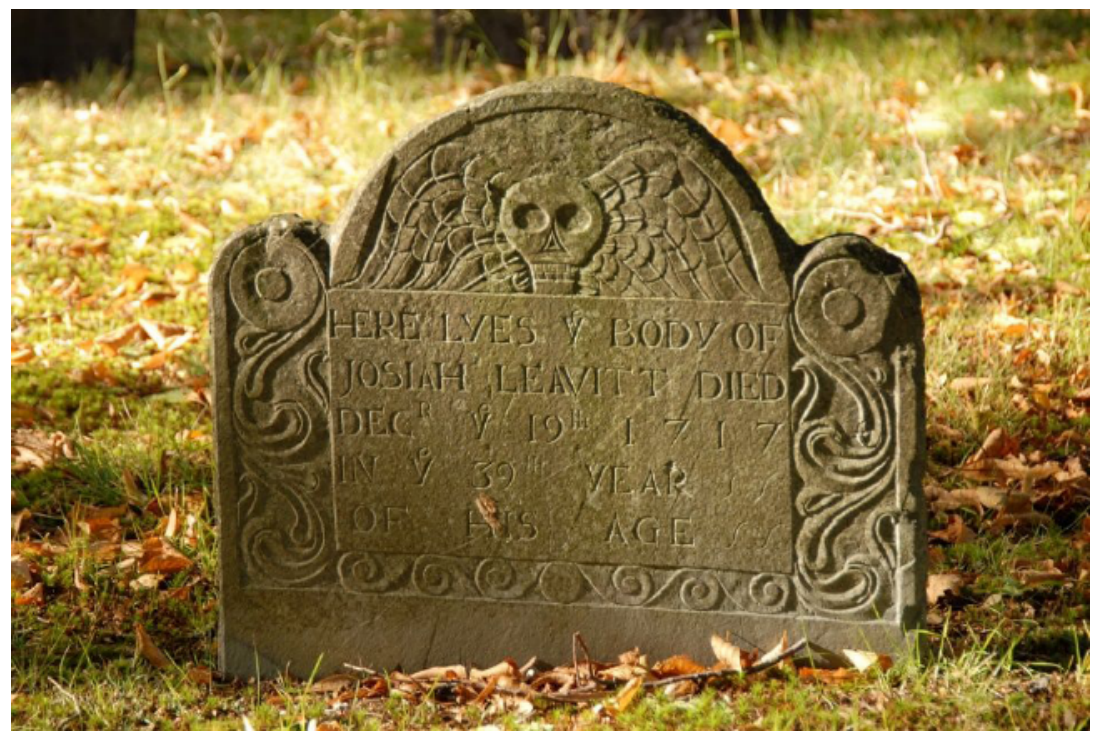

RYSUNEK 4. Dee E. Warenycia, zdjęcie nagrobka Josiaha Leavitta (zm. 19 grudnia 1717), Hingham Center Cemetery, Hingham, Plymouth Co., MA. Wikimedia Commons ${ }^{4}$.

W całym programie widać też inne zabiegi znane z twórczości Burtona, jak choćby częste u tego reżysera wykorzystanie postaci szkieletów i monstrów, m.in. głównego antagonisty Po drugiej stronie muru, Bestiusza (wydaje się on zbliżony także do kreatur z licznych ilustracji inspirowanych twórczością H. P. Lovecrafta). Przedstawianie czyhającego w mroku, budzącego lęk potwora przede wszystkim za pomocą konturowego zarysu postaci jest ponadto artystyczną reprezentacją tajemnicy oraz niepewności (Caillois, 1965/2005, s. 163). To, czego w pełni nie można zobaczyć, dostrzegając jednak fragmenty materialnego kształtu, może być bowiem o wiele bardziej przerażające niż jawnie ukazane zjawisko, z którym przyjdzie się zmierzyć; to, co ukryte, nie tylko przeraża, lecz także może wywołać dzikie i koszmarne fantazje. Dlatego właśnie postać Bestiusza w całej okazałości zostaje w serialu zaprezentowana tylko raz, przez ułamek sekundy - taki zabieg stanowi jednoczesną grę z percepcją i oczekiwaniami widzów.

4 Obraz na licencji Creative Commons - Attribution-ShareAlike 3.0 Unported (CC BY-SA 3.0). Pobrane z: https://creativecommons.org/licenses/by-sa/3.0/deed.en. 
$\mathrm{Na}$ tym nie koniec odniesień wizualnych serialu McHale'a do rozmaitych dzieł i tradycji. Kristiana Willsey (2016, s. 51) zwraca uwagę, że Po drugiej stronie muru stanowi specyficzny hołd dla historii książki ilustrowanej i animacji dla młodych odbiorców, czerpiąc inspiracje do intertekstualnych gier m.in. z kultury dziecięcej przełomu XIX i XX wieku. Przykładowo odcinek trzeci, Rozśpiewana szkółka (Campbell, Park, Cash, 2014), nawiązuje estetycznie do dziecięcych książek obrazkowych i ilustrowanych wydawanych w XIX wieku przez wydawnictwo McLoughlin Bros., a odcinek ósmy, Leśne dzieci (Bodnar, Campbell, Youn, Cash, 2014), odwzorowuje stylistykę prac ilustratora z początków XX stulecia, Winsora McCaya (Willsey 2016, s. 51), oraz wczesnych obrazów wytwórni Walta Disneya (aluzje do nich obecne są też $\mathrm{w}$ innych odcinkach). W serialu znajdziemy jednak również odwołania do nowszych produkcji, choćby nagrodzonego Oscarem filmu animowanego pt. Spirited Away. W krainie bogów (Suzuki, Miyazaki, 2003); można dostrzec np. pewne podobieństwo Cioci Szepcik z odcinka siódmego, Magiczny dzwoneczek (Herpich, McHale, Youn, Cash, 2014), do Yubaby, jednej z kluczowych postaci wspomnianego dzieła studia Ghibli. Niektóre sceny Po drugiej stronie muru zostały ponadto skonstruowane w taki sposób, by naśladować efekty uzyskiwane za pomocą określonych technik animacji. Przykładowo w odcinku czwartym, Pieśni mrocznej lampy (McLeod, Ward, Youn, Cash, 2014), krótki fragment taneczno-wokalny wykonuje rozbójnik. Mamy wówczas do czynienia $\mathrm{z}$ charakterystycznym odwzorowaniem ruchu i zaburzoną perspektywą (w odniesieniu do statycznego tła, na którym pojawia się postać) - w ten sposób w tej niedługiej scenie odzwierciedlono możliwości, które daje rotoskopia, czyli poklatkowe animowanie ruchu aktora, utrwalonego na taśmie filmowej, stosowane m.in. w animacjach braci Fleischer (Cartwright, 2012, s. 62).

Warstwa graficzna omawianej produkcji ma dodatkowy cel - tworzy także geograficzno-historyczne zakorzenienie dla fabuły. Po drugiej stronie muru jest bowiem z gruntu „amerykańskie”. O ile czerpie wiele inspiracji z tradycyjnych europejskich baśni czy podań ludowych, o tyle akcję osadza silnie w przeszłości USA, zwłaszcza w dawnych dziejach wiejskich terenów Stanów Zjednoczonych. Stroje postaci, architektura budynków, płynące po rzekach statki parowe - to rozpoznawalne i łatwe do zidentyfikowania sygnały historycznej „amerykańskości”. Na próżno szukać tu natomiast ruin średniowiecznych zamków czy innych materialnych znaków przeszłości Europy (poza sporadycznymi wyjątkami, by wspomnieć połączone posiadłości Quincy'ego Endicotta i Margueritte Grey, które cechują się efektowną mieszaniną stylu angielskiego i francuskiego rokoko, co wzmacnia obraz Nieznandii jako mozaiki epok i stylów), 
choć pozostają one obecne $\mathrm{w}$ warstwie narracyjnej. Taki zabieg wydaje się pełnić funkcję integrującą: choć środowisko i doświadczenia historyczne różnią się między kontynentami i zamieszkującymi je narodami, to dawne opowieści wciąż są zrozumiałe, a dzięki temu - możliwe do zaadaptowania w Nowym Świecie. Różnica wizualna, paradoksalnie, podkreśla tu wspólnotę marzeń, lęków i sposobów postrzegania świata przez pryzmat historii wywodzących się z podobnych źródeł.

Wszystkim opisanym wyżej zabiegom graficznym towarzyszą również inne sposoby kreowania świata serialowej narracji - elementy współgrające ze sobą i współtworzące nietypowe, acz jednocześnie spójne wewnętrznie uniwersum Po drugiej stronie muru.

\section{Muzyka, gra aktorska, liryczność}

Kolejną cechą wyróżniającą Po drugiej stronie muru spośród innych seriali animowanych jest ścieżka dźwiękowa tej produkcji. Silnie liryczna i wzorowana na twórczości z pierwszej połowy XX wieku muzyka została w znacznej części skomponowana i instrumentalnie wykonana przez zespół The Petrojvic Blasting Company (znany także jako The Blasting Company). Utwór tytułowy, Into the Unknown [Droga w nieznane], skomponowany został natomiast przez twórcę serialu, Patricka McHale’a. Ścieżka dźwiękowa doczekała się też osobnego wydania, m.in. na płycie winylowej uzupełnionej o zapis nutowy i teksty piosenek (Mondo, 2016). Większość utworów została udostępniona przez Cartoon Network w internecie.

W warstwie wokalnej przeważająca część piosenek wykonywana jest przez aktorów podkładających głosy pod poszczególne postaci. Polska wersja językowa serialu - co warto nadmienić - zawiera pełne tłumaczenie piosenek i również są one wykonywane przez aktorów użyczających głosu bohaterom. W obsadzie wersji oryginalnej znaleźli się m.in. Elijah Wood (Wirt), Collin Dean (Greg), Melanie Lynskey (Beatrice), Christopher Lloyd (Drzewiarz), Jack Jones (Żabuś) oraz artysta operowy Samuel Ramey (Bestiusz); w polskiej wersji językowej usłyszymy zaś Macieja Musiała (Wirt), Bernarda Lewandowskiego (Greg), Lidię Sadową (Beatrice), Andrzeja Blumenfelda (Drzewiarz), Arkadiusza Jakubika (Żabuś) oraz Dariusza Odiję (Bestiusz). Autorką polskich dialogów jest Dorota Filipek-Załęska, a za reżyserię dubbingu odpowiadała Dorota Matysiak.

Słowa wspomnianej wyżej piosenki przewodniej - w oryginale i w wersji polskiej - wprowadzają w dość melancholijną, spokojną atmosferę, co obrazuje tabela 1 . 
TABELA 1. Początkowe słowa piosenki przewodniej serialu Po drugiej stronie muru w oryginale i w oficjalnej polskiej wersji językowej

\begin{tabular}{|l|l|}
\hline \multicolumn{1}{|c|}{ Oryginał } & \multicolumn{1}{|c|}{ Oficjalna polska wersja językowa } \\
\hline Led through the mist & To, co przez mgłę blady księżyc wiódł w dal, \\
By the milk light of moon, & Dziś wraca tu, żyje znów. \\
All that was lost is revealed. & Czy troski minęły jak wiosny dawne dni? \\
Our long bygone burdens, & Co było? Co jest? \\
Mere echoes of the spring. & Gdzie los pchnąć nas chce? \\
But where have we come, & Choć mrzonką są sny, \\
And where shall we end? & Zagrajmy w tę grę. \\
If dreams can't come true, & Drzewa muska wiatr, \\
Then why not pretend? & Słychać liści szept. \\
& To jesień idzie już. \\
\hline
\end{tabular}

Opracowanie własne na podstawie oryginalnej i polskiej wersji serialu (McHale, 2014).

W tekście polskim można rozpoznać takie motywy jak przemijanie, śnienie, śmierć. Eksponowany jest tu ponadto popularny motyw pór roku (szczególnie jesieni), odnoszący się do etapów życia w kontekście np. dojrzewania, ale i odchodzenia. Co ciekawe, tekst angielski wydaje się bardziej dosadny i niesie większy ciężar gatunkowy. Pytanie przetłumaczone na polski jako „Gdzie los pchnąć nas chce?" w wersji oryginalnej brzmi And where shall we end? - w przekładzie widać więc nacisk na przyszłość, mniej bądź bardziej oczekiwaną, podczas gdy pierwowzór pyta właściwie: „Gdzie skończyć przyjdzie nam?”. Nacisk położony jest więc nie na „bycie popychanym przez los”, które nie ma określonego końca, a raczej na „skończenie”; to zaś kojarzyć się może nie tylko z zakończeniem przygody, lecz także ze znacznie poważniejszym końcem - śmiercią.

Ostatnie wersy piosenki pojawiają się dopiero w finałowym odcinku pt. Nieznandia (Allegri, Campbell, Herpich, Cash, 2014), kiedy to znana od początku linia melodyczna powraca, by ostatecznie zakończyć utwór. Wtedy widzowie mogą poznać zwieńczenie utworu (zaprezentowane w tabeli 2), nadające całości nowy sens i wchodzące jednocześnie w rezonans nie tylko z pierwszymi wersami piosenki, lecz także z całym serialem. Na poziomie wizualnym obserwujemy wówczas m.in. Drzewiarza, ponownie spotykającego córkę, czy Beatrice wraz z rodziną po zdjęciu klątwy przemieniającej ich wszystkich w ptaki. Jakkolwiek są to obrazy kojące, towarzyszące im słowa piosenki mogą sugerować, że to jedynie kłamstwa - szczęśliwe zakończenia, w które chcielibyśmy uwierzyć, gdyż nadają pozytywny wydźwięk całej historii, a nie dlatego, że są prawdziwe. 
TABELA 2. Końcowe słowa piosenki przewodniej serialu Po drugiej stronie muru w oryginale i w oficjalnej polskiej wersji językowej

\begin{tabular}{|l|l|}
\hline \multicolumn{1}{|c|}{ Oryginał } & \multicolumn{1}{c|}{ Oficjalna polska wersja językowa } \\
\hline How the gentle wind & Drzewa muska wiatr, \\
Beckons through the leaves, & Słychać liści szept. \\
As autumn colors fall. & Przemija jesień już. \\
Dancing in a swirl & Tańczy w tańcu kłamstw \\
Of golden memories, & Tych złotych wspomnień czar. \\
The loveliest lies of all, & Balsamem jest dla dusz, \\
The loveliest... lies... of all... & Balsamem... jest... dla dusz... \\
\hline
\end{tabular}

Opracowanie własne na podstawie oryginalnej i polskiej wersji serialu (Allegri, Campbell, Herpich, Cash, 2014).

Ponownie widać złagodzenie wydźwięku słów piosenki. Chociaż w obu wersjach pojawia się nawiązanie do jesieni - a tym samym, znów, motyw przemijania, to modyfikacjom uległy ostatnie trzy linijki. Polski przekład przedstawia wspomnienia jako coś magicznego, kojącego, przynoszącego ulgę, a na kwestię kłamstw - ze względu na przeniesienie refleksji na ten temat do centralnej części strofy - nie kładzie nacisku. W angielskiej wersji kłamstwo zostaje zaś zdecydowanie silniej wyeksponowane, a zakończenie piosenki ma inny wydźwięk, co udowadniamy we własnym roboczym przekładzie zaprezentowanym w tabeli 3.

TABELA 3. Końcowe słowa piosenki przewodniej serialu Po drugiej stronie muru w oryginale i w roboczym tłumaczeniu autorów artykułu

\begin{tabular}{|l|l|}
\hline \multicolumn{1}{|c|}{ Oryginał } & \multicolumn{1}{c|}{ Prósinowski i Krzywdziński } \\
\hline How the gentle wind & Jakże łagodny ten wiatr \\
Beckons through the leaves, & Pośród liści dmie, \\
As autumn colors fall. & Gdy opadają jesienne kolory. \\
Dancing in a swirl & Tańczą w piruecie \\
Of golden memories, & Pozłacanych wspomnień \\
The loveliest lies of all, & Najpiękniejsze ze wszystkich kłamstw, \\
The loveliest... lies... of all... & Najpiękniejsze... ze wszystkich... kłamstw... \\
\hline
\end{tabular}

Opracowanie własne na podstawie oryginalnej wersji serialu (Allegri, Campbell, Herpich, Cash, 2014).

Oczywiście tłumaczenie dosłowne pozbawia całość właściwego rytmu, lecz warto wskazać znaczenia, które uległy transformacjom w wyniku translacji. Oryginalne zwieńczenie piosenki nie oferuje, jak oficjalna wersja polska, samego ukojenia, prezentuje raczej gorzkie przyjęcie do wiadomości kłamstwa, które - choć piękne - pozostaje fałszem. 
Utwór przewodni, także pod względem melodii i rytmu, wchodzi w rezonans z całą produkcją, odzwierciedlając właściwą temu serialowi melancholię, nostalgię i zadumę. Może jednak wpłynąć również na odbiór zakończenia owej historii: mimo że na ekranie widzimy szczęśliwe zwieńczenia różnych wątków, to słyszymy utwór opowiadający o „pięknych kłamstwach”, co może pozostawić widza tak ze wzruszeniem, jak z pewnym zwątpieniem, czy to co, zobaczył, faktycznie miało miejsce.

\section{Nawiq̨zania historyczne i kulturowe}

Jak wspomniano już wcześniej, Po drugiej stronie muru jest produkcją bazującą na licznych odniesieniach kulturowych. Jest to dostrzegalne tak w warstwie graficznej i dźwiękowej, jak w skonstruowaniu postaci oraz samej narracji. Wiele spośród tych odniesień ma charakter swoistej lokalizacji - przeniesienia znanych i rozpoznawalnych motywów obecnych w kulturze zachodnioeuropejskiej (i nie tylko) oraz dopasowania ich do amerykańskiego kontekstu. O ile serial jest generalnie przystępny dla hipotetycznych młodych odbiorców, o tyle zrozumienie dużej części szczegółowych nawiązań może wymagać znacznej wiedzy i kapitału kulturowego. Za przykład mogą posłużyć wspomniane już graficzne odniesienia serialu McHale’a do książek oficyny McLoughlin Bros. czy prac ilustratora Winsora McCaya (pierwsze z tych odwołań pojawia się $\mathrm{w}$ produkcji także w sposób dosłowny - taką samą nazwę jak przywołane wydawnictwo nosi bowiem statek, którym bohaterowie podróżują w odcinku szóstym; Edward, Youn, Cash, 2014).

Same imiona głównych bohaterów i innych postaci występujących w produkcji niosą ze sobą znaczenia, które na pierwszy rzut oka mogą nie być oczywiste. Starszy z braci, Wirt, w nawiązaniu do niemieckiego słowa Wirt - 'gospodarz', pełni funkcję „gospodarza” całej opowieści jako centralna postać, z którą projektowany widz ma się domyślnie utożsamiać i której ma towarzyszyć. Z charakteru racjonalny, ale też neurotyczny, prezentowany jest on też jako chłopiec o silnie artystycznym duchu. W trudnych chwilach często ucieka się do poetyckich metafor czy wręcz wypowiada swe myśli wierszem. Młodszy brat, Greg (z łacińskiego Gregorius i greckiego Grēgórios - 'czujny', 'uważny'), prezentuje zgoła inną postawę życiową. Choć z pozoru niepoważny i dziecinny, wydaje się dużo bardziej otwarty na otaczającą go rzeczywistość - często stosuje rozwiązania, które w normalnych okolicznościach zdawać by się mogły pozbawione sensu. W odcinku trzecim wykorzystuje np. piosenkę, by rozweselić grupę zwierząt i odwrócić ich uwagę od niedostatków jedzenia, a w szóstym przebiera się za bęben, by pomóc innym bohaterom w podszyciu 
się pod członków orkiestry. Nawiązuje też przyjaźń ze znalezioną po drodze żabą - narratorem całej opowieści i jednocześnie swoistym zwierzęcym przewodnikiem.

Wiele wskazuje również na to, że imiona niektórych bohaterów powiązane są z główną konstrukcją narracyjną samej produkcji, która odwołuje się wyraźnie do Boskiej komedii Dantego Alighieri (1472/1978) - w przeważającej mierze do jej części poświęconej podróży po Piekle. Wirt odgrywa tu zdecydowanie rolę Dantego, któremu towarzyszy Greg wcielający się poniekąd w Wergiliusza - swym zachowaniem, bardziej niż słowami, zdaje się objaśniać realia Nieznandii. Nie przypadkiem pierwszą napotkaną przez braci postacią jest mówiący ludzkim głosem ptak - błękitnik o imieniu Beatrice (pol. Beatrycze), takim samym jak imię przewodniczki po Raju i ukochanej Dantego opiewanej przezeń w wierszach (Ascoli, 2007, s. 52). Znamienny jest też fakt, że inicjalny odcinek kończy się wypowiadanym przez Drzewiarza ostrzeżeniem przed Bestiuszem, który „gasi wszelką nadzieję” (Allegri, Gorman, Wolfhard, Cash, 2014), polując na zbłąkane w lesie dusze. Jest to bezpośrednie echo inskrypcji zdobiącej bramy piekielne u Dantego, a jednocześnie, dla bohaterów serialu, stanowi początek wyprawy i zapowiedź nadchodzących wyzwań.

Należy również zwrócić uwagę na silną paralelę pomiędzy konstrukcją serialu a Dantejską podróżą przez Piekło. W kolejnych odcinkach bracia napotykają galerię różnorodnych postaci stanowiących reminiscencje kolejnych infernalnych kręgów, gdzie cierpią dusze dręczone przez własne błędy czy wady charakteru. To np. nauczycielka miotana tęsknotą za kochankiem w odcinku Rozśpiewana szkótka (odniesienie do pożądania; Campbell, Park, Cash, 2014) czy magnat handlowy, którego bogactwo jest tak wielkie, że nie zna nawet wielkości swego pałacu, w odcinku Szalona miłość (nawiązanie do chciwości; Allegri, Gorman, Cash, 2014). Porządek ten zostaje zachowany w kontekście podstawowych praw rządzących światem narracji. By kontynuować podróż, bracia muszą przeprawić się przez rzekę, za co, jak się dowiadują, wymagana jest opłata w wysokości dwóch „grosików”; zamiast łodziami Charona, u Dantego przewożącego zmarłych przez Acheront, lub Flegiasza, przewoźnika przez Styks, bohaterowie płyną parostatkiem, którego głównymi pasażerami są antropomorficzne żaby.

W ramach odwołującej się do Boskiej komedii interpretacji serialowej opowieści Bestiusz (w oryginalne the Beast - 'bestia') odgrywa oczywiście rolę Szatana. We własnej osobie pojawia się on rzadko - zwykle widać go tylko jako cień wśród drzew. Jak już zostało wspomniane, jego postać zostaje w pełni zaprezentowana tylko w jednej scenie - okazuje się, że jest pokracznym monstrum, którego zdrewniałe ciało wydaje się złożone z zamarłych w wyrazie 
grozy twarzy. Rogaty stwór żywiący się duszami zagubionych podróżników nie tylko doskonale wpisuje się w odczytanie serialu w kluczu bazującym na dziele Dantego, lecz także reprezentuje szerszą kategorię popkulturowych satanicznych antagonistów działających w ciemności i z ukrycia, a uosabiających mroczną stronę osobowości samych bohaterów. Bestiusz jest bowiem groźny nie tyle z uwagi na swoją potęgę, ile dlatego, że eksploatuje ludzką rozpacz, smutek czy autodestrukcyjne tendencje człowieka (w odniesieniu do horroru w ogóle o takim zjawisku pisze Anita Has-Tokarz, 2011, s. 287, 289, 297). Tak postępuje np. z Drzewiarzem, którego historię przytoczyliśmy wcześniej.

Trzeba wyraźnie zaznaczyć, że Boska komedia, choć zdecydowanie służy za podstawę głównej osi fabularnej serialu, nie stanowi jedynego źródła inspiracji twórców Po drugiej stronie muru. Wiele obecnych w produkcji motywów zaczerpnięto wprost $\mathrm{z}$ tradycyjnych europejskich oraz amerykańskich baśni i legend. Wiodący czarny charakter, mimo że pełni naczelną funkcję Szatana, w zakresie wyglądu i zachowania reprezentuje inspiracje zaczerpnięte $\mathrm{z}$ rozlicznych źródeł. Postać Bestiusza może bowiem przywodzić na myśl np. wizerunki Wendigo lub innych istot nadprzyrodzonych z podań sprzed okresu kolonialnego. Jego specyficznym atrybutem jest latarnia, która - jak pamiętamy - mieści w sobie duszę owego stworzenia, a tym samym jest jego słabym punktem, co stanowi znany motyw obecny w baśniach, mitach i legendach Z różnych rejonów świata (Frazer, 1890/2009, s. 1559-1584).

Po drugiej stronie muru nie korzysta jednak z prostego i bezrefleksyjnego przeniesienia rozpoznawanych motywów kulturowych - możemy tu raczej mówić o swoistej relokacji i rekonceptualizacji określonych idei. Przede wszystkim, jak już wspomnieliśmy, zmieniony zostaje kontekst historyczny i geograficzny rozmaitych opowieści. Jakkolwiek Nieznandia wydaje się krainą poza czasem, dysponującą własną osobliwą geografią (co skądinąd typowe dla baśniowych narracji; Nikolajeva, 2003, s. 141), rozpoznawalna jest jednocześnie jako tereny przypominające Stany Zjednoczone z przełomu XVIII i XIX wieku (z pewnymi anachronizmami, co potwierdza tezę, że owa czasoprzestrzeń wykracza poza normalny bieg dziejów). Przemawiają za tym, przypomnijmy, stroje postaci, specyficzna architektura budynków, nietrudne do zidentyfikowania rozwiązania techniczne (choćby przywołany wcześniej charakterystyczny rzeczny parostatek z odcinka szóstego). Nawet jasne sugestie, że podróż bohaterów prowadzi ich po zaświatach, podlegają tu swoistej adaptacji geograficznej. W odcinku drugim pt. Perypetie na święcie plonów (McHale, Renier, Youn, Cash, 2014) bohaterowie trafiają do niewielkiej wioski, zamieszkałej przez - z pozoru mężczyzn i kobiety o dyniach w miejscu głów, świętujących nadchodzący czas żniw kukurydzy. Jak się później okazuje, są to przebrani zmarli (ukazani jako 
szkielety), co nabiera szczególnego znaczenia w kontekście nazwy samej wioski, Pottsfield (potter's field - 'pole garncarza' - to nazwa cmentarza dla ludzi ubogich lub o nieznanej tożsamości). Przywódcą społeczności jest natomiast budzący respekt osobnik obdarzony imieniem biblijnego proroka Enocha. Nawet archaiczne elementy są więc $\mathrm{w}$ serialu adaptowane do nowych warunków historycznych, kulturowych i geograficznych.

Charakterystycznym aspektem tych przeniesień jest swoista kreatywna reinterpretacja. Serial wykorzystując wiele motywów z legend, baśni czy dzieł literackich stanowiących fundamenty zachodniego dziedzictwa kulturowego, często adaptuje je w formie zmuszającej do zadania pytań o ich głębszy sens i znaczenie. Jak zostało wcześniej wspomniane, na początku pierwszego odcinka bracia ratują z opresji ptaka - Beatrice, która w podzięce oferuje im wsparcie (Allegri, Gorman, Wolfhard, Cash, 2014; to motyw powszechny w wielu tradycyjnych baśniach, gdzie protagonistom pomagają tzw. donatorzy). Bohaterowie dopiero później dowiadują się, że całe zajście zostało zainscenizowane przez samą Beatrice, która chciała wciągnąć chłopców w pułapkę. W odcinku siódmym (Herpich, McHale, Youn, Cash, 2014) Wirt i Greg trafiają do domu starej kobiety, kojarzącej się z baśniową wiedźmą, która używa magicznego dzwoneczka, by kontrolować młodą siostrzenicę. Bracia usiłują pomóc dziewczynie (zakładają, że jest ona ofiarą czarownicy), by odkryć, że - inaczej niż w klasycznych historiach - staruszka jedynie próbowała chronić podopieczną przed złym duchem, który ją opętał. W ostatnim odcinku serii (Allegri, Campbell, Herpich, Cash 2014) Bestiusz obiecuje natomiast Gregowi pomoc w powrocie do domu, jeśli bohater wypełni zlecone przez antagonistę niezmiernie trudne zadania. Chłopiec przynosi więc kłębek pajęczyny, gdy proszony jest o szpulę srebrnej nici, i wykorzystuje iluzję optyczną, otrzymawszy polecenie złapania słońca do filiżanki. Stosuje więc spryt, by sprostać niewykonalnym wyzwaniom. Okazuje się jednak, że padł ofiarą podstępu - dowiadujemy się, że Bestiusz wymyśla kolejne misje, zajmując czymś młodszego z braci, by nie zwrócił on uwagi, iż opada z sił i powoli zamarza na śmierć wśród szalejącej śnieżycy. Tego rodzaju zabiegi pokazują, że nie zawsze wzór zachowania, który znamy z baśni, jest właściwy w konkretnej sytuacji. Nie jest to jednak zjadliwa krytyka czy sugestia bezsensowności tych opowieści, a raczej wskazówka, że nie zawsze prosty morał jest najlepszą nauczką, którą możemy z nich wynieść.

Po drugiej stronie muru można określić jako serial intertekstualny, sięgający w warstwie narracyjnej do licznych źródeł: od europejskich baśni, legend, podań ludowych, przez Boską komedię Dantego, po popularne wyobrażenia o przeszłości Stanów Zjednoczonych. Korzystając z tych inspiracji, nie tylko reinterpretuje je i spaja w nową całość, lecz przede wszystkim toczy z odbiorcą grę 
bazującą na rozpoznawaniu motywów i archetypów kulturowych (Muszyńska, 2011, s. 297). Nie każdy widz będzie w stanie dostrzec wszystkie aluzje, zapożyczenia czy parafrazy - znaczna część z nich pozostaje jednak, przynajmniej na podstawowym poziomie, czytelna dla publiczności niezależnie od wieku czy indywidualnych kompetencji kulturowych.

\section{Nastrój i emocje}

Specyficzny nastrój oraz główne emocje, które kryją się w Po drugiej stronie muru, są podobne do tych właściwych literaturze gotyckiej, horrorowi czy wiktoriańskim ghost stories - dostrzeżemy więc w serialu przede wszystkim poczucie tajemnicy, mocno splatające się z grozą i nostalgią. Przestrzeń jesiennego lasu epatuje melancholią, a wiele postaci napotkanych przez Wirta i Grega wydaje się odczuwać trudną do opisania tęsknotę - jak choćby bogaty Quincy Endicott, który mimo znacznego majątku cierpi z powodu braku życiowego celu bądź też poczucia sensu własnej egzystencji. Jednocześnie, wśród cieni, na bohaterów wciąż czyha zagrożenie, czy to w postaci budzącego grozę Bestiusza, czy rozmaitych przerażających stworzeń, jak choćby podobne do wilka czy ogromnego psa monstrum atakujące chłopców w pierwszym odcinku produkcji.

Chociaż w animacji znalazła się także przestrzeń dla żartów, to humor wydaje się tu funkcjonować jako element wprowadzający chwile odpoczynku od mrocznych sekretów, problemów i wątpliwości, które towarzyszą odkrywaniu w tej opowieści kolejnych wątków i obserwowaniu zachodzących w niej zwrotów akcji. Taka funkcja żartów nie umniejsza jednak ich wartości. Choć bowiem Po drugiej stronie muru można zaklasyfikować jako dreszczowiec, a nawet horror dla dzieci (i nie tylko), to właśnie humorystyczne sceny i dialogi ujawniają złożoność sytuacji, w której znaleźli się bohaterowie. Można tu wskazać wątek kamyka z namalowaną twarzą, znajdującego się w posiadaniu Grega - chłopiec kilkakrotnie posługuje się nim, aby przytoczyć żartobliwe „fakty”, takie jak np. informacja, że dinozaury miały uszy, ale nikt o tym nie wie, bo nie zachowały się z nich żadne kości. Dopiero pod koniec serialu dowiadujemy się, że bohater dręczony był wyrzutami sumienia z powodu kradzieży kamienia $\mathrm{z}$ ogrodu sąsiadki - humorystyczna funkcja tego przedmiotu zyskuje zatem nowy wymiar.

Po drugiej stronie muru intencjonalnie żongluje więc komizmem i grozą lub tragizmem, paradoksalnie naśladując realia codzienności. Jest to ciekawe zwłaszcza w kontekście dominującej w świecie Zachodu wizji dzieciństwa, gdyż omawiana animacja staje się dowodem na zasadność tworzenia masowych produkcji, które nie stronią od emocji uważanych za trudne. 
Dużo łatwiej jest opowiadać - zwłaszcza dzieciom - o miłości, przyjaźni, braterstwie, szczerości i szczęściu niż o poczuciu lęku, wyobcowania, złości, smutku oraz o doświadczeniach takich jak śmierć. Wszystkie te zjawiska są w końcu elementem rzeczywistości, w której żyje człowiek. Jak pisze Antoni Kępiński (1977/2012), „świat otaczający roi się od różnego rodzaju niebezpieczeństw i nie możemy przed nim wciąż się wycofywać, trzeba iść naprzód, a to wymaga odwagi" (s. 239). Świat dzieci, tak jak świat dorosłych, nie jest idealny - uniwersum dzieciństwa nie jest zatem wolne od lęków, grozy, niebezpieczeństw czy śmierci. Chociaż nierzadko chcielibyśmy chronić młodych ludzi przed tym, co trudne, np. stosując rozmaite tabu, to nie jesteśmy w stanie zaprzeczyć prawom życia i otaczającej rzeczywistości, która - niezależnie od naszych chęci - zawsze obejmuje także to, co drażliwe: smutek, zazdrość, poczucie niesprawiedliwości.

Ciekawe jest jednak, jaką funkcję pełnią teksty grozy (książki, gry, animacje itd.) w odniesieniu do doświadczania codzienności. Jak zauważa Michał Kruszelnicki (2010, s. 70), człowiek doświadczający horroru5 - literackiego, filmowego czy „zaklętego” w grze wideo - może doznawać go na własnych warunkach, $\mathrm{z}$ bezpiecznej perspektywy, np. w domowym fotelu: antycypując pewne wydarzenia, przeżywając je przez pryzmat losów bohaterów, nie jest bowiem jednocześnie wystawiony na to samo niebezpieczeństwo, co fikcyjne postaci. Można tu mówić o swojego rodzaju spektaklu kontrolowanym przez odbiorcę - spektaklu, który może zaoferować „straszne katharsis”. Autorzy tekstów grozy są więc, jak pisze przywołany badacz (s. 77), potężnymi twórcami, którzy posiadają zdolność do uzewnętrzniania naszych wewnętrznych lęków, zmuszając nas do zmierzenia się z owymi lękami. Eksternalizując mroczne fantazje, poprzez kontrolowaną grozę pozwalają na okiełznanie drzemiących w nas niepokojów.

Oczywiście jest to zjawisko ryzykowne, zwłaszcza w kontekście dzieci jako odbiorców - szczególnie że warunkiem powodzenia zarysowanego wyżej procesu jest właśnie odczuwanie bezpieczeństwa, które w przypadku najmłodszych łatwo zachwiać (Slany, 2016, s. 52). Jednakże Po drugiej stronie muru bierze pod uwagę, kim są odbiorcy. Nie zderza dziecka z tym, co w nas - dorosłych - budzi taką samą grozę (chociażby ze względu na zastosowaną w serialu formę wizualną i formułę opowiadania). Mimo że śmierć jest zjawiskiem trudnym dla każdego, niezależnie od wieku, serial McHale’a opowiada o niej z bezpiecznego dystansu. Choć wykorzystuje mechanizmy grozotwórcze, nie wystawia odbiorcy na bezpośrednie, obezwładniające działanie horroru, jak dzieje się

5 Kruszelnicki odnosi się głównie do horroru literackiego, ale jego spostrzeżenia można odnieść także do innych form horrorów i dreszczowców, w tym - do animacji. 
często w produkcjach dla dojrzałych widzów, a stosując okazjonalny humor, pozwala na zaczerpnięcie oddechu i przypomnienie sobie, że życie nie składa się jedynie z lęku.

\section{Potencjał Po drugiej stronie muru}

Biorąc pod uwagę powyższe rozważania, można uznać, że animacje takie jak Po drugiej stronie muru mają wysoki potencjał edukacyjny, wychowawczy, kulturowy i emocjonalny. Warto wspomnieć w tym miejscu również o pozytywnym odbiorze, z jakim spotkała się ta produkcja wśród widzów i krytyków. Dowodem może być uhonorowanie jej licznymi branżowymi wyróżnieniami. Na szczególną uwagę zasługują dwie nagrody Emmy: jedna w kategorii najlepszego programu animowanego, druga - dla dyrektora artystycznego, Nicka Crossa - w kategorii najlepszego indywidualnego osiągnięcia w animacji. Serial otrzymał też nagrodę dla najlepszej produkcji animowanej na Międzynarodowym Festiwalu Animacji w Ottawie w roku 2015. Wśród recenzentów dominujące były pozytywne opinie dotyczące jakości samej animacji oraz innowacyjnej formuły programu, wychodzącego poza ramy przyjęte we współczesnych produkcjach animowanych (np. Bree, 2014). Mimo że Po drugiej stronie muru to dzieło o wysokim poziomie złożoności, dość wymagające pod względem odbiorczym, nie odstrasza to widzów, a wręcz przeciwnie - spotyka się z pozytywną recepcją tak wśród krytyków, jak nieprofesjonalnej publiczności, o czym świadczy np. wygrana w plebiscycie Teen Choice Awards.

Po drugiej stronie muru i inne podobne programy, jako projekty wielopłaszczyznowe, zawierające liczne nawiązania do rozmaitych utworów i tradycji, mogą być postrzegane jako dzieła postmodernistyczne (w omawianym przypadku - wręcz jako baśnie postmodernistyczne), zwłaszcza w zakresie prowadzonej w nich gry z rozpoznawalnymi przez odbiorców motywami kulturowymi (Kostecka, 2014, s. 54). Takie produkcje otwarte są też na analizę w kontekście pozostałych aspektów kultury, posiadają bowiem wysoki potencjał intertekstualny i intersemiotyczny oraz stają się przestrzenią edukacyjną, oczekując na (re)interpretacje. Niewątpliwie rzeczywistość również wymaga umiejętności analizy, zwłaszcza w obliczu zmian obowiązujących paradygmatów myślowych oraz potrzeby społecznego tworzenia nowych sensów codzienności. Potencjał ten jest istotny jednak nie tylko w procesie edukacji młodych pokoleń, lecz także w odniesieniu do rozwoju wszystkich grup wiekowych. Bogactwo wykorzystanych motywów i wątków kulturowych otwiera się bowiem nie na jedną grupę demograficzną, a tworzy przestrzeń edukacyjną dla 
wszystkich. Tam, gdzie młodsi dostrzegą odniesienia np. do najnowszych dzieł popkultury, dorośli dojrzą mniej bądź bardziej wyraźne odwołania do motywów literackich, konkretnych utworów, historii, w tym historii sztuki, animacji itp. Można więc postawić pytanie, czy różni odbiorcy obcują z tym samym dziełem. Mimo że w artykule nie to jest przedmiotem naszej analizy, pozwolimy sobie na porównanie omawianego serialu (chociaż nie dotyczy to wyłącznie Po drugiej stronie muru) do swego rodzaju rozdroża, na którym spotkać się mogą rozmaici aktorzy życia społecznego - ludzie w różnym wieku, różnego pochodzenia oraz z różnymi doświadczeniami.

$\mathrm{Z}$ wychowawczego punktu widzenia potencjał omawianej produkcji nabiera znaczącej wagi. Wychodzimy bowiem z założenia, że zależy nam, dorosłym, na wychowaniu społeczeństwa gotowego do krytycznych analiz rozmaitych tekstów oraz dostrzegania w nich np. archetypów kulturowych. Wspólne oglądanie i omawianie animacji, takich jak np. serial McHale’a, może także, w aspekcie wychowawczym, prowadzić do nauki dostrzegania detali, do zadawania pytań, do rozbudzania ciekawości, rozwijanej później także w relacji z bliskimi ludźmi. Od rodzinnego seansu Po drugiej stronie muru można bowiem przejść do wspólnego przeglądania publikacji McLoughlin Bros. lub odkrywania muzycznych inspiracji twórców ścieżki dźwiękowej serialu, jak również do przypomnienia sobie znanych już wcześniej utworów. To nauka przechodzenia pomiędzy różnymi istotnymi perspektywami, być może też pierwszy krok do rozbudzania wyobraźni socjologicznej (Mills, 1959/2007) - na poziomie niekoniecznie akademickim, lecz niezmiernie istotnym, gdyż umiejętność owego przechodzenia pomiędzy perspektywami (a także motywami, ujęciami, tekstami) w podstawowej wersji ma szansę stać się istotną kompetencją transgresyjnego i wielokontekstowego świata XXI wieku. Dotyczy to, ponownie, nie tylko najmłodszych - mamy na myśli kształtowanie i trenowanie owej umiejętności w kontekście edukacji i wychowania w ujęciu całościowego rozwoju. Na szczęście wydaje się, że coraz częściej produkcje animowane (zarówno te skierowane do młodszych, jak i starszych odbiorców) doceniają kompetencje widzów - wymagając od nich spostrzegawczości oraz umiejętnego odczytywania intertekstualnych zapożyczeń, a także bawiąc się formą i formułą opowiadania historii. O ile Po drugiej stronie muru korzysta ze znanych motywów kulturowych, o tyle innowacyjność produkcji jest w dużej mierze rezultatem ich określonej kompozycji i szczególnego sposobu przedstawiania (Mittel, 2013, s. 60)

Jednocześnie, co warto przypomnieć, w serialu McHale’a obecna jest refleksja na temat śmierci i tego, co po niej następuje - powszechna współcześnie $\mathrm{w}$ popkulturze. $\mathrm{W}$ produkcji dostrzec można zadumę nad filozoficzną 
kwestią końca, cykliczności, przemijania oraz wizji zaświatów, co czyni z pozornie „niepoważnej” animacji dzieło operujące tanatycznym katharsis poprzez uzewnętrznienie i zmaterializowanie mortualnego dyskursu. Podobnie jak w przypadku używanego przez Kruszelnickiego (2010, s. 69-70) pojęcia „strasznego katharsis” mamy tu do czynienia ze swoistym oczyszczeniem odbiorcy z negatywnych uczuć związanych z doświadczeniem śmierci i straty poprzez ekspozycję na treści o nich mówiące. Projektując nasze uczucia i emocje na bohaterów oraz identyfikując się z postaciami, mamy niejako możliwość udziału w stanach, których doświadczają - ale jednocześnie jesteśmy świadomi fikcyjności całej sytuacji oraz przekonani o własnym bezpieczeństwie.

Zarówno główni bohaterowie, jak i postacie, które napotykają na drodze, osiągają wyzwolenie lub zwycięstwo poprzez pogodzenie się ze zmianami, przemijaniem, stratą i wreszcie - przez zrozumienie samych siebie. Najbardziej dobitnym przykładem jest ostateczna konfrontacja z Bestiuszem, w której uczestniczą Wirt i Drzewiarz. Gdy próby fizycznego atakowania potwora zawodzą, monstrum próbuje przekonać Wirta, by został jego nowym sługą. Obiecuje, że w zamian umieści żywot Grega w czarodziejskiej lampie, gdzie będzie on bezpieczny tak długo, jak długo latarnia będzie podsycana kolejnymi duszami zebranymi w lesie. Bestiusz ponosi klęskę, którą przypieczętowuje zdanie sobie przez Wirta sprawy z absurdalności owej obietnicy, z bezsensu egzystencji skupiającej się jedynie na podsycaniu bladego wspomnienia o utraconych osobach i dobrowolnym pogrążaniu się w rozpaczy. Zrozumienie własnego smutku i zaakceptowanie żalu związanego ze stratą paradoksalnie przynosi wyzwolenie $\mathrm{z}$ beznadziei - ostatni odcinek prezentuje bowiem taką wizję biegu wydarzeń, w której Wirtowi udaje się uratować siebie i brata przed śmiercią w wodach jeziora (choć i to, zgodnie z końcowymi słowami piosenki przewodniej, może być „pięknym kłamstwem”). Program zderza więc odbiorców ze wspomnianym już mortualnym dyskursem, pozwala na myślowe zmierzenie się z ostatecznością, a także na jej oswojenie. Co ciekawe, forma zastosowana w realizacji Po drugiej stronie muru umożliwia dostosowanie tanatycznego katharsis do emocjonalnego poziomu odbiorców - zapewne młodsi, niezaznajomieni np. z Boskq komedią, obcować będą z mniej rozbudowaną koncepcją śmierci niż ta, której doświadczać będą starsi, znający dzieło Dantego. Można więc powiedzieć, że animacja McHale’a otwiera się na kognitywną personalizację, zostawiając odbiorcom przestrzeń na takie pojęcie dyskursu o śmierci, na jakie są w danym momencie gotowi.

Po drugiej stronie muru nie tylko w konstruktywny sposób czerpie z szerokiej palety elementów kultury symbolicznej, lecz także samo stanowi rodzaj współczesnej, postmodernistycznej baśni. O ile przyjemne i interesujące może 
być już oglądanie i wyszukiwanie kolejnych parafraz i odniesień do utworów literackich, filmowych czy muzycznych, o tyle jednym $z$ bardziej istotnych elementów budujących jakość tego serialu jest psychologiczny efekt wywierany przez produkcję na odbiorcy. W ostatecznym rozrachunku postacie i miejsca składające się na Nieznandię stanowią eksternalizację ludzkich problemów, marzeń i obaw. Przerażający Bestiusz uosabia depresję, rezygnację i utratę nadziei - tak jak służący mu Drzewiarz reprezentuje poczciwą duszę, pchaną do złych czynów przez irracjonalne zaprzeczanie faktom i niemożność pogodzenia się z utratą najbliższej osoby. Podobnie też, jak w każdej baśni o potencjale terapeutycznym, ostatecznym celem protagonistów nie jest odniesienie zwycięstwa za pomocą fizycznej siły czy samego tylko sprytu, ale na drodze zrozumienia samych siebie, akceptacji własnych emocji i uczuć (Bettelheim, 1976/2010, s. 52) 6 . Świat „po drugiej stronie” nie jest bardziej zły czy okrutny od rzeczywistego. Ubrany $\mathrm{w}$ formę dzieła sztuki, stanowi jednak bezpieczną przestrzeń eksploracji naszego życia wewnętrznego (Spitz, 2016, s. 481-482).

\section{Zakończenie}

Kultura współczesna bawi się nie tylko nowymi formami, lecz także klasycznymi ideami i historycznymi oraz wciąż popularnymi gatunkami: powieścią gotycką, dreszczowcem, horrorem, baśnią oraz narracją przygodową. Chociaż $\mathrm{w}$ artykule skupiliśmy się na serialu animowanym, podobne tendencje da się zauważyć także $\mathrm{w}$ rozwoju innych mediów, np. gier wideo. Jako przykłady można wskazać wykorzystującą podobne motywy co Po drugiej stronie muru grę Little Misfortune (Killmonday Games, 2019), wizualnie intrygujące Limbo (Playdead, 2010) czy grozotwórczą rosyjską produkcję Knock-knock (Ice-Pick Lodge, 2013).

Tego rodzaju teksty kultury nie tylko wzbudzają szeroki wachlarz emocji począwszy od strachu przez ciekawość po rozbawienie, lecz także zachęcają do spojrzenia na codzienne zjawiska z nowej perspektywy. Oferują katharsis - nie zawsze "grzeczne”, a zorientowane na trudne tematy oraz na społeczne tabu. Powtórzmy, że doskonałym przykładem takiego dzieła jest Po drugiej stronie muru - animacja, która odbija w zwierciadle ekranu uniwersalne uczucia i lęki, kierując przekaz do różnorodnych widzów i tym samym skłaniając do refleksji

6 Jakkolwiek psychoanalityczna interpretacja baśniowej narracji może budzić wątpliwości natury metodologicznej (Bednarek, 2017, s. 208), nie odrzucamy całkowicie płynących $\mathrm{z}$ takiej lektury wniosków. 
całą rzeszę zdywersyfikowanych odbiorców popkultury; animacja, która - jak wiele innych współczesnych produkcji tego rodzaju - wciąż odnawia swój język (Mąka-Malatyńska, 2016, s. 148), jednocześnie nie zapominając o tradycji i spuściźnie historycznej. Co ważne, takie programy telewizyjne coraz częściej postrzegane są jako istotne elementy współczesnego życia kulturalnego i przemysłu rozrywkowego.

Biorąc to wszystko pod uwagę, ważnym postulatem jest dalsze badanie popkultury, także dziecięcej, w różnych jej przejawach przez socjologów, pedagogów i psychologów, gdyż w tekstach owej kultury nierzadko kryją się idee dotyczące tak ludzkich lęków i pragnień, jak społecznej przeszłości, teraźniejszości, ale i czasów, które dopiero nadejdą. Dzieła takie jak Po drugiej stronie muru stymulują dyskusje toczone dziś, jak również uwrażliwiają na przyszłość, która, jak można podejrzewać, malować się będzie nie tylko w jasnych, radosnych barwach, lecz także w tych ciemnych. Nie można o tym zapomnieć, pracując ze współczesnymi dyskursami, kształcąc i wychowując nowe pokolenia.

\section{Bibliografia}

Abbate, A. (prod.), Burton, T. (prod. i reż.), Johnson, M. (reż.). (2005). Corpse Bride [Gnijąca panna młoda] [film]. USA: Warner Bros.

Alighieri, D. (1978). Boska komedia (E. Porębowicz, tłum.). Warszawa: PIW. (wyd. oryg. 1472).

Allegri, N., Campbell, J., Herpich, T. (scen.), Cash, N. (reż.). (2014). Chapter 10: The Unknown [Nieznandia] [odcinek serialu telewizyjnego]. W: P. McHale (prod.), Over the garden wall [Po drugiej stronie muru]. Atlanta, GA, New York, NY, Burbank, CA: Cartoon Network.

Allegri, N., Gorman, Z. (scen.), Cash, N. (reż.). (2014). Chapter 5: Mad love [Rozdział 5. Szalona miłość] [odcinek serialu telewizyjnego]. W: P. McHale, Over the garden wall [Po drugiej stronie muru]. Atlanta, GA, New York, NY, Burbank, CA: Cartoon Network.

Allegri, N., Gorman, Z., Wolfhard, S. (scen.), Cash, N. (reż.). (2014). Chapter 1: The old grist mill [Rozdział 1. Stary młyn] [odcinek serialu telewizyjnego]. W: P. McHale (prod.), Over the garden wall [Po drugiej stronie muru]. Atlanta, GA, New York, NY, Burbank, CA: Cartoon Network.

Ascoli, A. R. (2007). From auctor to author: Dante before the Commedia. W: J. Rachel (red.), The Cambridge companion to Dante: Second edition (s. 46-66). Cambridge, New York, NY: Cambridge University Press.

Bednarek, M. (2017). Władca baśni. Wokół polskiej recepcji Cudownego i pożytecznego Brunona Bettelheima. Porównania, 20, 199-217. https://doi.org/10.14746/p.2017.20.12796. 
Bender, M., Hashimoto, R., Wilson, L. (prod.), Burton, T. (reż.). (1988). Beetlejuice [Sok z żuka] [film]. USA: Warner Bros.

Bettelheim, B. (2010). Cudowne i pożyteczne. O znaczeniach $i$ wartościach baśni (D. Danek, tłum.). Warszawa: W.A.B. (wyd. oryg. 1976).

Bocquelet, B. (prod.). (2011-2019). The amazing world of Gumball [Niesamowity świat Gumballa] [serial telewizyjny]. Atlanta, GA, New York, NY, Burbank, CA: Cartoon Network.

Bodnar, M., Campbell, J., Youn, B. (scen.), Cash, N. (reż.). (2014). Chapter 8: Babes in the woods [Rozdział 8. Leśne dzieci] [odcinek serialu telewizyjnego]. W: P. McHale (prod.), Over the garden wall [Po drugiej stronie muru]. Atlanta, GA, New York, NY, Burbank, CA: Cartoon Network.

Bree, J. (2014, 11 kwietnia). Over the Garden Wall is the best thing that the Cartoon Network has done - review. Agents of Geek. Pobrane z: https://www.agentsofgeek. com/2014/11/over-the-garden-wall-is-the-best-thing-that-the-cartoon-networkhas-done-review/.

Browngardt, P., Funaro, M. (prod.), McHale, P. (reż.). (2013). Tome of the Unknown: Harvest melody. USA: Cartoon Network.

Caillois, R. (2005). W sercu fantastyki (M. Ochab, tłum.). Gdańsk: Słowo/Obraz Terytoria. (wyd. oryg. 1965).

Campbell, J., Park, L. (scen.), Cash, N. (reż.). (2014). Chapter 3: Schooltown follies [Rozdział 3. Rozśpiewana szkółka] [odcinek serialu telewizyjnego]. W: P. McHale (prod.), Over the garden wall [Po drugiej stronie muru]. Atlanta, GA, New York, NY, Burbank, CA: Cartoon Network.

Cartwright, L. (2012). The hands of the animator: Rotoscopic projection, condensation, and repetition automatism in the Fleischer apparatus. Body \& Society, 18(1), 47-78. https://doi.org/10.1177/1357034X11432562.

Czubaszek, M. (2019, 28 sierpnia). Tessa Moult-Milewska. Nie trzymać się kurczowo rzeczywistości. Papaya.Rocks. Pobrane z: https:/papaya.rocks/pl/people/tessamoult-milewska-nie-trzymac-sie-kurczowo-rzeczywistosci.

Edison, T. (prod.), Dawley, J. S. (reż.). (1910). Frankenstein. USA: Edison Manufacturing Company.

Edwards, N., Youn, B. (scen.), Cash, N. (reż.). (2014). Chapter 6: Lullaby in Frogland [Rozdział 6. Żabia kołysanka] [odcinek serialu telewizyjnego]. W: P. McHale (prod.), Over the garden wall [Po drugiej stronie muru]. Atlanta, GA, New York, NY, Burbank, CA: Cartoon Network.

Frazer, J. G. (2009). The golden bough. A study of magic and religion. Auckland: The Floating Press. (wyd. oryg. 1890).

Fyfe, K. (2006). Wolves in sheep's clothing: A content analysis of children's television. Los Angeles, CA, Alexandria, VA: Parents Television Council. Pobrane z: https:// issuu.com/parentstv.org/docs/2006_wolvesinsheepsclothing. 
Gorman, Z., Nguyen, V.-D., Sanchez, C. (scen.), Cash, N. (reż.). (2014). Chapter 9: Into the Unknown [Droga w nieznane] [odcinek serialu telewizyjnego]. W: P. McHale (prod.), Over the garden wall [Po drugiej stronie muru]. Atlanta, GA, New York, NY, Burbank, CA: Cartoon Network.

Has-Tokarz, A. (2011). Horror w literaturze wspótczesnej i filmie. Lublin: Wydawnictwo UMCS.

Herpich, T., McHale, P., Youn, B. (scen.), Cash, N. (reż.). (2014). Chapter 7: The ringing of the bell [Magiczny dzwoneczek] [odcinek serialu telewizyjnego]. W: P. McHale (prod.), Over the garden wall [Po drugiej stronie muru]. Atlanta, GA, New York, NY, Burbank, CA: Cartoon Network.

Hunt, P. (2008). Literatura dla dzieci a dzieciństwo. W: M. J. Kehily (red.), Wprowadzenie do badań nad dzieciństwem (M. Kościelniak, tłum., s. 61-83). Kraków: WAM. (wyd. oryg. 2004).

Ice-Pick Lodge. (2013). Knock-knock [gra wideo]. Moscow: Ice-Pick Lodge.

İvrendi, A., Özdemir, A. A. (2010). Mothers' evaluation of cartoons' influence on early childhood children. Procedia - Social and Behavioral Sciences, 2(2), 2561-2566. https://doi.org/10.1016/j.sbspro.2010.03.373.

Kępiński, A. (2012). Lęk. Warszawa: Wydawnictwo Literackie. (wyd. oryg. 1977).

Killmonday Games. (2019). Little misfortune [gra wideo]. Hedemora: Killmonday Games. Kostecka, W. (2014). Baśń postmodernistyczna: przeobrażenia gatunku. Intertekstualne gry z tradycja literacką. Warszawa: Wydawnictwo SBP.

Kruszelnicki, M. (2010). Oblicza strachu. Tradycja i współczesność horroru literackiego. Toruń: Adam Marszałek.

Mąka-Malatyńska, K. (2016). Od Fantazji do Gumballa - estetyka filmu animowanego. Polonistyka. Innowacje, 3, 135-150. https://doi.org/10.14746/pi.2016.1.3.13.

McHale, P. (prod.). (2014). Over the garden wall [Po drugiej stronie muru] [serial telewizyjny]. Atlanta, GA, New York, NY, Burbank, CA: Cartoon Network.

McHale, P., Renier, A., Youn, B. (scen.), Cash, N. (reż.). (2014). Chapter 2: Hard times at the huskin' bee [Perypetie na święcie plonów] [odcinek serialu telewizyjnego]. W: P. McHale (prod.), Over the garden wall [Po drugiej stronie muru], Atlanta, GA, New York, NY, Burbank, CA: Cartoon Network.

McLeod, S., Ward, P., Youn, B. (scen.), Cash, N. (reż.). (2014). Chapter 4: Songs of the dark lantern [Rozdział 4. Pieśni mrocznej lampy] [odcinek serialu telewizyjnego]. W: P. McHale (prod.), Over the garden wall [Po drugiej stronie muru]. Atlanta, GA, New York, NY, Burbank, CA: Cartoon Network.

Mills, C. W. (2007). Wyobraźnia socjologiczna (M. Bucholc, tłum.). Warszawa: WN PWN. (wyd. oryg. 1959).

Mittel, J. (2013). Phineas \& Ferb: Children's television. W: E. Thompson, J. Mittel (red.), How to watch television (s. 56-64). New York, NY, London: New York University Press. 
Mondo. (2016). Over the Garden Wall original television soundtrack!. Mondo Shop. Pobrane z: https://mondoshop.com/blogs/news/over-the-garden-wall.

Muszyńska, A. (2011). Intertekstualność jako forma dialogu kulturowego. Przekłady Literatur Słowiańskich, 2(1), 295-305.

Nikolajeva, M. (2003). Fairy tale and fantasy: From archaic to postmodern. Marvels \& Tales, 17(1), 138-156.

Petru, S. (2010-2011). The power of colour. Préhistoire, Art et Sociétés, 65-66, 17131723.

Playdead. (2010). Limbo [gra wideo]. Copenhagen: Playdead, Microsoft Games Studios.

Pugh, T. (2011). Innocence, heterosexuality and queerness of children's literature. https://doi.org/10.4324/9780203831410.

Rudin, S., Schroeder, A. (prod.), Burton, T. (reż.). (1999). Sleepy Hollow [Jeździec bez głowy] [film]. USA: Paramount Pictures.

Slany, K. (2016). Groza w literaturze dziecięcej. Od Grimmów do Gaimana. Kraków: WN UP.

Sorin, R. (2003). Validating young children's feelings and experiences of fear. Contemporary Issues in Early Childhood, 4(1), 80-89. https://doi.org/10.2304/ ciec.2003.4.1.8.

Spitz, E. H. (2016). Revisiting fairy tales. Contemporary Psychoanalysis, 52(3), 478488. https://doi.org/10.1080/00107530.2016.1149416.

Spufford, F. (2002). The child that books built. London: Faber \& Faber.

Sugar, R. (prod.). (2013-2019). Steven Universe. USA: Atlanta, GA, New York, NY, Burbank, CA: Cartoon Network.

Suzuki, T. (prod.), Miyazaki, H. (reż.). (2003). Sen to Chihiro no kamikakushi [Spirited away. W krainie bogów] [film]. Japonia: Studio Ghibli, Toho.

Szkudlarek, T., Melosik, Z. (2010). Kultura, tożsamość i edukacja. Migotanie znaczeń. Kraków: Impuls. (wyd. oryg. 1998).

Tymińska, M. (2016). Kreskówkowe transgresje - o animowanych serialach Cartoon Network i ich recepcji. W: D. Bruszewska-Przytuła, M. Cichmińska, P. Przytuła (red.), Seriale w kontekście kulturowym. Sfery życia - z życia sfer (s. 29-45). Olsztyn: Instytut Polonistyki i Logopedii UWM.

Van Orman, T. (prod.). (2008-2010). The marvelous misadventures of Flapjack [Niezwykłe przypadki Flapjacka] [serial telewizyjny]. Atlanta, GA, New York, NY, Burbank, CA: Cartoon Network.

Ward, P. (prod.). (2010-2018). Adventure time [Pora na przygodę!] [serial telewizyjny]. Atlanta, GA, New York, NY, Burbank, CA: Cartoon Network.

Willsey, K. (2016). "All that was lost is revealed": Motifs and moral ambiguity in Over the Garden Wall. Humanities, 5(3), 51. https://doi.org/10.3390/h5030051. 